PEDAGOGIA : Jurnal Ilmu Pendidikan

\title{
MODEL PENGEMBANGAN INTERNASIONALISASI PROGRAM AKADEMIK PENDIDIKAN TINGGI
}

\author{
Nur Aedi \\ Departemen Administrasi Pendidikan \\ Fakultas Ilmu Pendidikan \\ Universitas Pendidikan Indonesia \\ nuraedi@upi.edu
}

\begin{abstract}
Abstrak
Penelitian ini bertujuan untuk mengembangkan sebuah program internasionalisasi pada unit kerja Fakultas Ilmu Pendidikan Universitas Pendidikan Indonesia sehingga terciptanya daya saing secara institusional dan nasional. Untuk mencapai tujuan tersebut, maka diperlukan informasi yang akurat, oleh sebab itu dilakukan eksplorasi penelitian secara sistemik. Secara khusus penelitian ini mendeskripsikan dan menganalisis : Gambaran empirik umum sistem kelembagaan Fakultas Ilmu Pendidikan Universitas Pendidikan Indonesia. Gambaran empirik sistem kepegawaian di lingkungan Fakultas Ilmu Pendidikan Universitas Pendidikan Indonesia. Gambaran empirik kondisi kondisi kompetensi pendidik dan tenaga administrasi di lingkungan Fakultas Ilmu Pendidikan Universitas Pendidikan Indonesia. Gambaran empirik kondisi mutu layanan di Fakultas Ilmu Pendidikan Universitas Pendidikan Indonesia. Rancangan program strategi pencapaian program internasionalisasi di lingkungan Fakultas Ilmu Pendidikan dapat membangun daya saing nasional. Percepatan tujuan-tujuan tersebut belum sepenuhnya dapat dilakukan. Oleh sebab itu diperlukan pendekatan baru dalam peningkatan kualitas akadmik dan non akademik, yakni pengembangan internasionalisasi program bagi pendidik dan tenaga kependidikan di lingkungan Fakultas Ilmu Pendidikan Universitas Pendidikan Indonesia.
\end{abstract}

Kata Kunci: Pengembangan; Internasionalisasi; Program Akademik

\begin{abstract}
This study aims to develop an internationalization program in the work unit of the Faculty of Education, University of Indonesia so that institutional and national competitiveness is created. To achieve these objectives, accurate information is needed, therefore systemic research exploration is carried out. In particular, this study describes and analyzes: General empirical description of institutional systems, Faculty of Education, University of Education, Indonesia, empirical description of the staffing system in the Faculty of Education, University of Education in Indonesia, An empirical description of the condition of service quality in the Faculty of Education, University of Indonesia Education, the design of the program strategy for achieving internationalization programs within the Faculty of Education can build national competitiveness. Acceleration of these objectives has not been fully implemented. Therefore a new approach is needed in improving academic and non-academic quality, namely the development of internationalization of programs for educators and education staff in the Faculty of Education, Universitas Pendidikan Indonesia.
\end{abstract}

Keywords: Development; Internationalization ; Academic Programs 


\section{A. PENDAHULUAN}

Memasuki era globalisasi Indonesia dihadapkan pada berbagai permasalahan yang memiliki tingkat kompleksitas yang tinggi. Permasalahan yang pertama yaitu bagaimana Bangsa Indonesia harus mampu bertahan dari berbagai kendala baik dari dalam negeri ataupun dari luar negeri. Dengan adanya era globalisai akses informasi yang akan semakin terbuka, batas antar negara sulit untuk dipisahkan sehingga ancaman yang berupa propaganda yang menyesatkan bagi Negara Kesatuan Republik Indonesia akan mudah digoyah dari luar negeri. Kendala yang datang dari dalam negeri adalah berkenaan dengan semakin memudarnya rasa persatuan dan kesatuan bangsa, terbukti dengan semakin makin maraknya kelompok-kelompok yang ingin memisahkan diri dari Negara Kesatuan Republik Indonesia.

Permasalahan yang kedua adalah dengan beralihanya sentralisasi menuju desentralisasi memberikan dampak yang luar biasa terhadap perubahan segala aspek tatanan pemerintahan baik politik, sosial, ekonomi, budaya dan pendidikan. Peralihan sentralisasi menuju desentralisasi pendidikan merupakan terobosan besar dalam pembangunan bangsa yang selama ini memakai paradigma top-down berubah menjadi memakai paradigma bottom-up. Kebijakan Pemerintah pusat telah menetapkan bahwa otonomi daerah dilaksanakan pada tahun 2001 yang mencakup berbagai bidang termasuk dalam bidang pendidikan.

Ketiga kualitas sumber daya manusia di indonesia masih rendah jika dibandingkan dengan negara lain, berdasarkan laporan Political and Economic Risk Consultancy (PERC) yang berkedudukan di Hongkong, sebagaimana dimuat dalam The Jakarta Post (Vol.19, No.127: 2001), dijelaskan bahwa sistem pendidikan Indonesia adalah yang terburuk di Asia. Mutunya masih di bawah Negara Vietnam dan Negara-negara tetangga di Asia. Menurut survei Political and Economic Risk Consultant (PERC) dalam Mediarti (2013), pendidikan nasional kita berada pada peringkat $12 \mathrm{di}$ bawah Vietnam. Sedangkan ranking pertamanya adalah Korea Selatan. Hal ini sangat penting sekali bagi seluruh komponen bangsa berupaya meningkatkan mutu pendidikan, terutama mutu dari sumber daya manusia yang dimiliki.

Fokus permasalahan penelitian ini adalah bagaimana cara membangun daya saing pada unit kerja Fakultas Ilmu Pendidikan Universitas Pendidikan Indonesia agar dapat kompetitif di tingkat nasional dan internasional. Pertanyaan penelitian adalah: Bagaimana gambaran umum sistem kelembagaan Fakultas Ilmu Pendidikan Universitas Pendidikan Indonesia? Bagaimana sistem kepegawaian di lingkungan Fakultas Ilmu Pendidikan Universitas Pendidikan Indonesia? Bagaimana kondisi kondisi 
kompetensi tenaga pendidik dan tenaga administrasi di lingkungan Universitas Pendidikan Indonesia? Bagaiamana kondisi mutu layanan di Fakultas Ilmu Pendidikan Universitas Pendidikan Indonesia? Bagaiamana strategi pencapaian program internasionalisasi di lingkungan Fakultas Ilmu Pendidikan dapat membangun daya saing nasional ?

\section{B. TINJAUAN PUSTAKA}

\section{Kompetensi dan Internasionalisasi}

Kompetensi diartikan sebagai sesuatu yang dimiliki oleh individu yang melekat pada perilakunya. Posuma (2013) mengemukakan bahwa kompetensi merupakan kemampuan untuk melaksanakan atau melakukan suatu pekerjaan yang dilandasi atas keterampilan dan pengetahuan. Kompetensi dapat dilihat dari kemampuannya, kecakapannya ataupun dari pengetahuannya. Hal ini sependapat dengan beberapa ahli di antaranya Anna Mariana dalam Rais (2014), mendefinisikan kompetensi sebagai berikut:. Competency (n) is being competent, ability (to the work) (Hornby, dkk, 1962: 192,. Competent (adj) refer to (person) having ability, power, authority, skill, knowledge, etc (to do what is needed) (Hornby, dkk, 1962:193)and competency is a rational performance which satisfactorily meets the objective for a desire condition (Johnson, dkk, 1974).

Anna Mariana mendefinisikan kompetensi kedalam tiga definisi diantaranya pada definisi pertama menunjukkan bahwa kompetensi itu pada dasarnya menunjukkan kepada kecakapan atau kemampuan untuk mengerjakan sesuatu pekerjaan. Sedangkan definisi kedua menunjukkan bahwa kompetensi pada dasarnya merupakan sifat atau karakteristik orang-orang kompeten, yakni memiliki kecakapan, daya (kemampuan), otoritas (kewenangan), kemahiran (keterampilan), pengetahuan, dan sebagainya untuk mengerjakan apa yang diperlukan. Kemudian definisi ketiga, menyatakan kompetensi adalah menunjukkan kepada tindakan (kinerja) rasional yang dapat mencapai tujuantujuannya secara memuaskan berdasarkan kondisi (prasyarat) yang diharapkan.

Jika merujuk pada Kamus Umum Bahasa Indonesia (1994) “ Kompetensi berarti (kewenangan) kekuasaan untuk menentukan atau memutuskan sesuatu hal". Pengertian dasar kompetensi (competency) adalah kemampuan atau kecakapan. Definisi kompetensi menurut Kamus Umum Bahasa Indonesia hampir sama dengan pendapat Anna Mariana di atas, bahwa pada dasarnya kompetensi memiliki kecakapan dan kemampuan dimensi kecakapan dan kemampuan sangat melekat sekali terhadap orang yang memiliki kompetensi.

Istilah kompetensi sebenarnya memiliki banyak makna sebagaimana dikemukakan oleh Dadang Budiadji dalam Santiasih (2013) mengemukakan bahwa kompetensi merupakan 
pengetahuan keterampilan, kemampuan atau karakteristik kepribadian sesoarang yang secara langsung mempengaruhi kinerjanya. Sedangkan karakteristik kepribadian itu sendiri meliputi value, self image, belief dan motives.

Sedangkan menurut Nick Boulter dkk (2003, hlm. 41), menyatakan bahwa komptensi adalah suatu karakteristik dasar dari seseorang yang memungkinkannya memberikan kinerja unggul dalam pekerjaan, peran atau situasi tertentu. Dari kedua definisi di atas terdapat dimensi keterampilan dan karakteristik kepribadian atau karakteristik dasar. Dari pendapat pertama yakni menyatakan bahwa kompetensi lebih kepada pengetahuan keterampilan dan karakterisitk pribadi. Karakteristik pribadi di sini dapat dilihat dari perilaku, perkataan ataupun penampilan yang mempengaruhi kinerjanya dalam melakukan pekerjaan. Sedangkan pendapat yang kedua lebih kepada karakteristik dasar dari manusia seperti kepribadian dan perilaku yang ditampilkan.

\section{Mutu Layanan Pendidikan Tinggi}

Sebagai salah satu bentuk jasa yang melibatkan interaksi yang tinggi antara penyedia dan pemakai jasa. Kualitas pelayanan merupakan suatu driver kepuasan yang bersifat multidimensi. Tingkat kualitas pelayanan tidak dapat dinilai berdasarkan sudut pandang perusahaan tetapi harus dipandang dari sudut pandang penilaian pelanggan (Rinala, 2013). Terdapat lima dimensi pokok yang menentukan kualitas penyelenggaraan pendidikan, Parasuraman, Zeithami, \& Berry, (1985) yaitu: (1) Keandalan (reliability), yakni kemampuan memberikan pelayanan yang dijanjikan secara tepat waktu, akurat, dan memuaskan. Beberapa contoh diantaranya: pengembangan bahan pembelajaran sesuai dengan kebutuhan (misalnya tuntutan keterampilan profesi dan dlunia kerja); jadwal kegiatan pelatihan dan ujian yang akurat; pelatihan yang berlangsung lancar; bimbingan yang lancar dan cepat; kepastian studi lanjut tenaga kependidikan yang terencana dan terlaksana dengan baik; dana penelitian tenaga kependidikan, dan kegiatan warga belajar dapat dilakukan secara tepat waktu dan tepat sasaran, sesuai dengan yang dijanjikan; (2) Daya tangkap (responsiveness), yaitu kemauan para tenaga kependidikan/pengelola untuk membantu para peserta didik/mahasiswa dan memberikan pelayanan dengan tanggap.

Dengan demikian, leader pada Pendidikan Tinggi harus mudah ditemui; dosen juga harus gampang ditemui mahasiswa untuk keperluan konsultasi; proses belajar hendaknya diupayakan interaktif dan memungkinkan para peserta didik mengembangkan seluruh kapasitas, kreativitas, dan kapabilitasnya; fasilitas pelayanan yang ada (perpustakaan, komputer, lab, dan ruang olahraga) harus 
mudah diakses oleh setiap insan yang terlibat dalam pendidikan dan pelatihan; prosedur administrasi perencanaan, pelaksanaan, dan evaluasi pendidikan dan pelatihan harus sederhana, tidak birokratik atau berbelit-belit. Dalam hal terjadi salah pelayanan, kemampuan untuk melakukan perbaikan secara tepat dan profesional bisa menciptakan persepsi kualitas yang sangat positif. Sebagai contoh, jika ada komputer yang rusak di lab komputer, harus segera diambil tindak lanjut, yaitu menginformasikannya kepada peserta pendidikan dan petatihan, dan segera memperbaikinya; (3) Jaminan (assurance), mencakup pengetahuan, kompetensi, kesopanan, respek terhadap pelanggan, dan sifat dapat dipercaya yang dimiliki para tenaga kependidikan; bebas dari bahaya, risiko atau keragu-raguan. Sebagai contoh, seluruh tenaga kependidikan harus benar-benar kompeten di bidangnya; reputasi penyelenggara pendidikan dan pelatihan yang positif di mata masyarakat; sikap dan perilaku seluruh tenaga kependidikan mencerminkan profesionalisme dan kesopanan; (4) Empati, meliputi kemudahan dalam melakukan hubungan, komunikasi yang baik, perhatian pribadi, dan memahami kebutuhan para pelanggan. Misalnya, fasilitator mengenal nama para peserta pendidikan dan pelatihan yang menempuh mata latihan yang disampaikannya; setiap fasilitator bisa dihubungi dengan mudah, baik di ruang kerja, via telepon, maupun e-mail;
(5) Bukti langsung (tangibles), meliputi fasilitas fisik, perlengkapan, tenaga kependidikan, dan sarana komunikasi. Misalnya berupa gedung, fasilitas komputer, fasilitas perpustakaan, ruang kelas, ruang fasilitator, ruang seminar, media pembelajaran, kantin, tempat parkir, jurnal ilmiah, sarana ibadah, fasilitas olahraga, laboratorium, penampilan dan busana tenaga kependidikan.

\section{METODE PENELITAN}

Penelitian ini tidak dirancang untuk menguji hipotesis, dari suatu pengaruh atau hubungan antara variabel, akan tetapi mendeskripsikan data, fakta, dan kecenderungan yang terjadi, selanjutnya dianalisis dan direkomendasi apa yang harus dibangun untuk mencapai suatu keadaan. Penelitian ini, secara konsep dikategorikan pendekatan studi kasus kualitatif dengan penyajian deskriptif analitik.

Tingkat kelembagaan yang dijadikan sumber data yaitu seluruh komponen yang berada dilingkungan Fakultas Ilmu Pendidikan Universitas Pendidikan Indonesia yang sumber data otentiknya diambil dari Dekan, Pembantu Dekan I, Pembantu Dekan II, dosen, pegawai administrasi. dan mahasiswa yang dipandang relevan untuk memberikan informasi atau komentar tentang masalah yang diidentifikasi, ditentukan secara "snowball" sesuai 
dengan tujuan penelitian dan data yang diharapkan.

Penentuan responden dalam penelitian ini dipilih secara purposif dan ditetapkan dengan teknik bola salju, sesuai dengan kebutuhan. Data dan informasi yang diperlukan dalam penelitian ini antara lain: (1) sistem klelembagaan di lingkungan Fakultas Ilmu Penididikan; (2) Sistem kepegawaian di lingkungan Fakultas Ilmu Penididikan (3) Kompetensi tenaga dosen dan tenaga administrasi di lingkungan Fakultas Ilmu Penididikan (4) Mutu layanan di lingkungan Fakultas Ilmu Penididikan. Adapun teknik pengumpul data digunakan, studi dokumentasi; wawancara; observasi dan prediksi atau studi kecenderungan. Instrumen yang digunakan dalam penelitian kualitatif adalah manusia, dan alat seperti buku catatan, tape recorder dan kamera. Sebagai pedoman instrumen dirancang pokok-pokok informasi dan data yang diperlukan disusun oleh peneliti melalui proses diskusi dengan para ahli yang relevan.

\section{HASL DAN PEMBAHASAN}

\section{Sistem Kelembagaan di Lingkungan}

Fakultas Ilmu Pendidikan Universitas Pendidikan Indonesia.

Fakultas Ilmu Pendidikan merupakan bagian yang tidak terpisahkan dari Universitas Pendidikan Indonesia, hal ini dikarenakan kedudukan Fakultas
Ilmu Pendidikan adalah bagian dari sistem kelembagaan dari Universitas Pendidikan Indonesia. Oleh karena itu sistem kelembagaan secara keseluruhanakan mengacu pada sistem kelembagaan Universitas Pendidikan Indonesia. Dalam ketetapan MWA No. 14 Tahun 2005 MWA mengeluarkan Kebijakan Umum NonAkademik sebagai dasar hukum dalam merumuskan Rencana Strategis (Renstra) 2006-2010. Beberapa aspek penting dalam kebijakan non-akademik itu adalah: (a) Membangun kelembagaan UPI melalui reorganisasi, restrukturisasi, dan revitalisasi agar memiliki daya dukung yang kuat bagi pengembangan program akdemik dan program "income generating" yang didukung oleh sistem dan sumber daya yang memiliki kemampuan bersaing dalam membangun unjuk kerja dan kesejahteraan; (b) Membangun tata kelola universitas yang efesien dan efektif sesuai dengan kebutuhan dan perubahan mesyarakat dengan mengembangkan sistem manajemen korporasi universitas; (c) Modemisasi dan pemeliharaan fasilitas pendidikan dan penelitian secar optimal, termasuk infrstruktur teknologi informasi dan komunikasi untuk meningkatkan efektifitas, relevansi progam pendidikan, serta mutu proses dan hasil pembelajaran; (d) Meningkatkan kualitas, relevansi, serta diversifikasi produk-produk universitas di bidang pendidikan, penelitian, serta pelayanan dan pemberdayan masyarakat, dengan memperkuat jaringan kerja, 
kemitraan dan kerjasama dengan lembaga-lembaga lain secara nasional dan internasional; (e) Membangun sistem kepegawaian universitas yang efektif untuk meningkatkan kualitas budaya kerja, sistem rekrutmen, penempatan dan promosi, kinerja dan produktifitas, renumerasi inividual dan kelembagaan, propesionalisme, kualifikasi pendidikan, kompetensi kewirausahaan, loylitas, serta penabdi pada universitas dan (f) Membangun budaya kerja dengan memperkuat kepemimpinan, pengabdian, kebersamaan, pertisipasi, keunggulan kompetitif, dan kepelaporan untuk mempercepat proses transformasi UPI menuju universitas moderen berstandar internasional.

\section{Sistem kepegawaian di Lingkungan} Fakultas I lmu Pendidikan Universitas Pendidikan Indonesia.

\section{a. Rekrutmen}

Rekrutmen pegawai universitas Pendidikan Indonesia terutama tenaga akademik secara selektif sesuai dengan kebutuhan nyata universitas, tersusunnya pedoman pengalihan dan pengembangan pegawai universitas, dan penataan SDM sesuai dengan struktur organisasi UPI menurut PP Nomor 6 Tahun 2004 dan ART Tahun 2006. Pelaksanaan rekruitmen di Fakulas Ilmu Pendidikan di sesuaikan dengan formasi dan jatah quota yang diberikan oleh UPI dan Depdiknas. Pelaksanaan rekruitmen diarahkan pada calon pegawai yang memiliki syaratsyarat yang ditentukan.

\section{b. Pengembangan}

Pelaksanaan pembinaan sumber daya manusia di lingkungan Fakultas Ilmu Pendidikan universitas Pendidikan Indonesia disesuaikan dengan tuntutan UPI dan kebutuhan yang diperlukan. Tujuan dari pengembangan atau pembinaan adalah untuk meningkatkan kompetensi kepribadian, budaya kerja, dan displin kerja yang tinggi dalam kaitannya dengan kapasitas membangun lembaga, dan meningkatkan kualifikasi, mtu, dan jumlah sumber daya manusia.

\section{c. Penggajian}

Pelaksanaan sistem penggajian di lingkungan Fakultas Ilmu Pendidikan Universitas Pendidikan Indonesia, didasarkan pada berbagai peraturan di bawah ini, yaitu: Peraturan Pemerintah No 7 tahun 1977 jo. PP Nomor 9 tahun 2007 tentang Peraturan Gaji PNS, peraturan Presiden Nomor 59 Tahun 2007, tentang Tunjangan Dosen, peraturan Pemerintah Nomor 3 Tahun 2006 tentang Tunjangan Jabatan Struktural serta peraturan Presiden Nomor 12 Tahun 2006 tentang Tunjangan Umum PNS.

Seperti halnya Pegawai Negeri Sipil lainnya sistem pegajian di Uiversitas Pendidikan Indonesia terdiri dari gaji pokok, kepada Pegawai Negeri Sipil diberikan: (a) Tunjangan keluarga, (b) Tunjangan Jabatan, juga tunjangan 
pangan dan tunjangan-tunjangan lain. Bagi Pegawai Negeri Sipil yang mempunyai jabatan fungsional diberikan tunjangan jabatan fungsional seperti halnya dosen. Tunjangan Jabatan Fungsional yang dibayarkan dari pemerintah untuk Tenaga Dosen dan Tenaga Pustakawan, sementara bagi Tenaga Administrasi yang menduduki jabatan stuktural diberikan tunjangan jabatan struktural.

\section{d. Pemensiunan/Pemberhentian}

Sistem pemensiunan atau pemberhentian di Lingkungan Fakultas Ilmu Pendidikan Iuniversitas Pendidikan Indonesia adalah berbagai peraturan dibawah ini : peraturan Pemerintah Nomor 4 Tahun 1966 tentang Pemberhentian/Penghentian sementara PNS, peraturan Pemerintah Nomor 32 Tahun 1979 tentang Pemberhentian PNS beserta penjelasannya, peraturan Pemerintah Nomor 9 Tahun 2003 tentang Wewenang Pengangkatan, Pemindahan dan Pemberhentian PNS serta surat Edaran Kepada BAKN Nomor 04/SE/1980 tentang Pemberhentian PNS.

Sebagaimana ketentuan bagi Pegawai Negeri Sipil lainnya seorang PNS itu diberhentikan dengan mendapatkan hak pensiun apabila telah mencapai usia 56 tahun, kecuali Pegawai Negeri Sipil yang menduduki jabatan struktural eselon I dan II, dapat diperpanjang hingga 60 tahun, dan
Pegawai Negeri Sipil yang mempunyai jabatan fungsional dosen Lektor ke atas, usia pensiunnya sampai dengan 65 Tahun. Dalam kasus tertentu seorang dosen yang mempunyai jabatan Guru Besar dapat diperpanjang BUP nya sampai dengan 70 tahun.

\section{Kompetensi Dosen Dan Tenaga}

\section{Administrasi di Lingkungan} Fakultas Ilmu Pendidikan Universitas Pendidikan Indonesia.

Seiring dengan perubahan Universitas Pendidikan Indonesia menjadi Badan Hukum Milik negara (BHMN) peningkatan kompetensi sumber daya manusianya harus senantiasa mengamai peningkatan. Jika dilihat dari jumlah dosen yang memiliki tingkat pendidikan S3 di lingkungan Fakultas Ilmu Pendidikan Universitas Pendidikan Indonesia paling banyak dibandingkan dengan fakullas lain yang ada di UPI.

Berdasrkan wawancara dengan berbagai dosen lainnya dan pimpinan fakultas tenaga dosen selalu mengikuti berbagai perkembangan ilmu yang terus menerusmengalami perubahan. Hal ini juga ditunjang oleh tugas dan tanggung jawab dosen sebagai tenaga pengajar bagi mahasiswanya.

Hanya saja di dalam pengetahuan perkembangan mengenai teknologi, belum seluruhnya dosen paham betul akan perkembangan teknologi saat ini, khusunya teknologi yang mendukung proses belajar megajar. 
Dari segi keterampilan yang dimiliki oleh dosen secara umum sudah sngat baik, seperti dalam keterampilan mengajar dan berkomunikasi. Hanya dalam penguasaan teknologi belum begitu optimal. Yang menjadi perhatian dalam keterampilan dosen di lingkungan Fakultas Ilmu Pendidikan Universitas Pendidikan Indonesia adalah keterampilan dosen dalam menggunakan Bahasa inggris mayoritas belum begitu baik. Hal ini terlihat dari mayoritas tenaga dosen dalam prose belajar mengajar belum mampu menggunakan Bahasa Inggris. Sedangkan jika dilihat dai segi attitude/personallity sudah sangat baik terlihat dari adanya sikap keterbukaan dan budaya disiplin dalam bekerja.

Secara umum kondisi tingkat pendidikan tenaga administrasi di lingkungan FIP UPI minimal Strata 1 walaupun ada beberapa tenaga akademik yang sedang melanjutkan pendidikan ke jenjang S1. Kompetensi pegawai administrasi di lingkungan Fakultas Ilmu Pendidikan Universitas Pendidikan Indonesia sudah baik baik. Hal ini terlihat dari pengetahuan yang dimilikinya diantaranya pengetahuan mengenai ilmuilmu administrasi dan ilmu-imu pengetahuan lainnya. Keaktipan tenaga administrasi dalam mencari informasi mengeni perkembangan organisais khususnya UPI. Halini dimungkinkan karena, dengan adanya perubahan UPI yang begitu cepat akan menentukan masa depannya. Pengeahuan yang kurang begitu dimiliki oleh tenaga administarsi pada umumnya adalah pengetahuan akan perkembangan tehnologi.

Dari segi keterampilan tenaga administrasi di lingkungan Fakultas Ilmu Pendidikan Universitas Pendidikan Indonesia sudah baik, terlihat dari kemampuan dalam berkomunikasi dengan sesama rekan kerja dan berkomunikasi dengan pimpinan. Keterampilan dalam melakukan tugas-tugas administrasi seperti mengetik, membuat surat, mengumpulkan informasi dan menyusun laporan sudah sangat baik. Ada dua hal keterampilan yang kurang begitu baik yang dimiliki oleh tenaga administrasi diantaranya adalah keterampilan dalam menggunakan teknologi dan keterampilan dalam berbahasa Inggris.

\section{Mutu Layanan di Lingkungan Fakultas Ilmu Pendidikan Universitas Pendidikan Indonesia.}

Tujuan dari peningkatan mutu layanan adalah untuk memuaskan pelanggan. Dalam konteks penelitian ini adalah untuk memuasakan mahasiswa. Berbagai program dilaksanakan di lingkungan Fakultas Ilmu Pendidikan Universitas Pendidikan Indonesia salah satunya yaitu dengan upaya meningkatkan kualitas dari sarana prasarana.

Dari aspek reliabilitas kepercayaan terhadap pelanggan, animo masyarakat untuk masuk atau menyekolahkan anaknya ke jurusanjuran yang ada di lingkungan Fakultas Ilmu Pendidikan 
PEDAGOGIA : Jurnal IImu Pendidikan

sangat tinggi. Di dukung oleh status Perguruan Tinggi Negeri telah memberikan kpercayaan tersendiri pada masyrakat. Begitu juga dalam pelaksanaan pekerjaan baik dosen ataupun tenaga administrasi diarahkan untuk meningkatkan kepercayaan dari pelanggan khususnya mahasiswa. Dalam aspek respon terhadap kebutuhan pelanggan terutama mahasiswa belum optimla. Hal ini terlihat dari sulitnya mahasiswa untuk memberikan saran ataupun pendapat secara langsung dengan pihak lembaga. Kurangnya kegiatan survei kebutuhan pada mahasiswa yang dilakukan oleh lembaga menandakan bahwa lembaga kurang begitu respon terhadap kebutuhan ataupun kemamuan dari mahasiswa.

Dari aspek pemberian jaminan. Fakultas Ilmu Pendidikan, secara nyata terlibat dalam memberikan jaminan kepada lulusannya untuk menyediakan lapangan pekrjaan, kurang begitu optimal. Hal ini terlihat dari mayoritas lulusan dari jurusan yang ada di lingkungan Fakultas Ilmu Pendidikan tidak langsung di salurkan oleh pihak lembaga. Kerjasama dalam membangun lapangan pekerjaan dengan lembaga/instansi lain belum dioptimalkan.

Pada aspek adanya tindakanya nyata yang dilakukan pihak lembaga terhadap pelanggan belum sepenuhnya optimal, hal ini terlihat dari maih kentalnya birokrasi dalam kegiatan manajemen.

\section{Sistem Kelembagaan di Lingkungan \\ Fakultas Ilmu Pendidikan Universitas Pendidikan Indonesia. \\ Penetapan visi Universitas}

Pendidikan Indonesia sebagai Universitas

Pelopor dan Unggul (a leading and outstanding university) dalam disiplin ilmu pendidikan dan pendidikan displin ilmu di Indonesia pada 2010, dan menjadi salah satu universitas pelopor dan unggul di asia pada 2025. harus dapat dukung oleh seluruh komponen lembaga. visi tersebut memberikan makna bahwa kepeloporan keunggulan terletak pada unsur akademik dan kemahasiswaan dengan menempatkan sumber daya manusia sebagai pelaku utama untuk meraih dan mewujudkan kepeloporan keunggulan tersebut. Daya pikir dan kreativitas dosen maupun mahasiswa diposisikan sebagai kunci utama (producing machine) yang menghasilkan kepeloporan dan keunggulan, dengan didukung oleh modernisasi dan kelengkapan fasilitas pendidikan berstandar internasional.

Penetapan visi Universitas Pendidikan Indonesia tidak melalui proses yang begitu cepat, tetapi melalui proses yang begitu panjang. Transformasi kelembagaan UPI yang telah dimulai sejak 1999 perlu disesuaikan dengan perubahan dan tuntutan internal dan eksternal. Perubahan sistem kelembagaan berawal dari perubahan Institut Keguruan dan Ilmu Pendidikan (IKIP) menjadi Universitas Pendidikan Indonesia(UPI) dan kemudian menjadi UPI Badan Hukum Milik Negara 
(BHMN) memerlukan berbagai perencanaan yang strategis. Seperti halnya dalam Laporan Tahunan Universitas Pendidikan Indonesia (2006) menyebutkan beberapa fokus kebijakan untuk mempercepat proses transformasi kelembagaan Universitas.

Pertama, seluruh civitas akademika UPI diharapkan memiliki mindset atau cara pandang baru dalam menangani tugas dan memecahkan masalah sesuai dengan budaya korporasi, yang kesemuanya itu berpijak pada nilai-nilai inti: (1) Etos kerja sebagai bagian dari ibadah; (2) Orientasi terhadap kinerja (performance); (3) Orientasi terhadap mutu; (4) Partisipasi otonom yang didasarkan pada inisiatif mandiri dengan menghargai kemampuan dan prestasi orang lain; (5) Orientasi tepat waktu dan perencanaan jauh ke depan untuk meningkatkan kualitas lembaga dan layanan akademik kepada mahasiswa; dan (6) Semangat meneliti untuk menghasilkan karya-karya orisinil.

Kedua, diperlukan penataan sistem manajemen yang efektif dan efisien untuk mengelola semua aset dan fasilitas. Sebagai konsekuensi logisnya, diperlukan sumber-sumber keuangan yang tepat dan jelas, sehingga setiap kegiatan dapat didanai secara memadai untuk mencapai ambang batas kinerja yang memuaskan. Untuk itu UPI perlu memikirkan sumbersumber pendapatan lain, untuk mencukupi pendanaan bagi seluruh aktivitasnya.
Ketiga, instrumen penting lainnya untuk mendukung percepatan proses transformasi kelembagaan ialah implementasi kurikulum baru yang lebih adaptif terhadap perubahan dan tuntutan internal dan eksternal. Disamping itu, kurikulum baru diharapkan mampu menciptakan proses pembelajaran yang lebih berkualitas dan bermakna bagi mahasiswa.

Perubahan system kelembagaan di lingkungan Fakultas Ilmu Pendidikan mengalami berbagai perubahan, hal ini diakibatkan oleh struktur kebijakan di lingkungan Universitas Pendidikan Indonesia dan nasional mengalami perubahan.

Perubahan tersebut ditanggapi dengan sangat baik di lingkungan Fakultas Ilmu Pendidikan, dengan adanya peningkatan-peningkatan kinerja masingmasing unit kerja di lembaga. Hanya saja system kelembagaan di lingkungan Fakultas Ilmu Pendidikan belum mampu menciptakan system kelembagaan yang sudah mampu untuk bersaing secara internasional, hal ini terbukti dengan belum adanya jurusan atau program yang membuka kelas internasional di lingkungan Fakultas Ilmu Pendidikan. Dengan demikian perlu adanya peningkatan-peningkatan system kelembagaan di lingkungan Universitas Pendidikan Indonesia baik dalam peningkatan peran dan fungsi pimpinan ataupun optimalisasi dari komponen pegawai yaitu tenaga dosen dan tenaga 
administrasi.

\section{Sistem kepegawaian di Lingkungan}

Fakultas Ilmu Pendidikan Universitas Pendidikan Indonesia.

Sistem kepegawaian dalam hal Kebijakan penataan SDM di lingkungan Fakultas Ilmu Pendidikan umumnya di lingkungan Universitas Pendidikan Indonesia diwujudkan dalam program: (a) Pengembangan kode etik tenaga edukatif dan peneliti serta pedoman dan pelaksanaan penataan pegawai UPI sesuai dengan kebutuhan organisasi UPI berdasarkan PP No. 6 Tahun 2004 dan ART UPI; (b) Pengembangan pedoman dan pelaksanaan rekrutmen pegawai universitas, terutam tenaga akademik, sesuai dengan kebutuhan universitas; () Pengembangan pedoman dan pelaksanaan pembinaan SDM universitas sesuai dengan tutntutan UPI-BHMN; (d) Peningkatan kompetensi kepribadian, kompetensi sosial, kompetensi pedagogis, kompetensi profesional, dan budaya kerja dalam kaitannya dengan kapasitas membangun universitas; dan (e) Peningkatan kualifikasi, mutu, dan jumlah SDM.

\section{Kompetensi dosen dan tenaga} administrasi di Lingkungan Fakultas Ilmu Pendidikan

\section{Universitas Pendidikan Indonesia}

Kompetensi tenaga dosen dan tenaga administrasi yang ada di lingkungan Fakultas Ilmu Pendidikan Universitas Pendidikan Indonesia sudah baik, hal ini terlihat dari adanya pengetahuan yang dimiliki, keterampilan yang dimiliki dan attitude/personality. Kompetensi tenaga dosen dan tenaga administrasi memberikan pengaruh yang sangat besar terhadap pencapaian visi Universitas Pendidikan Indonesia secara umum dan kesuksesan pelaksanaan program di lingkungan Fakultas Ilmu Pendidikan.

Tenaga dosen harus mempunyai kualifikasi yang diperlukan bagi penyampain ilmunya kepada Mahasiswa. Dengan tenaga dosen yang berkompeten dan berkualitas akan memudahkan penyampaian ilmu pengetahuan dan teknologi sehingga apa yang disampaikan kepada mahasiswa dapat diterima dan dikembangkan sesuai dengan kemampuan mahasiswa dengan kajian bidang ilmu yang dipilihnya.

Disamping itu juga dapat dilihat dari klasifikasi pendidikan (S2/S3) dan jenjang jabatan akademiknya. pengelolaan mutu Dosen dapat dilakukan melalui peningkatan pendidikan ke strata yang lebih tinggi di Universitas Universitas Negeri maupun swasta terbaik di dalam maupun diluar negeri secara bertahap dan berencana.

Berbagai perubahan yang terjadi secara keseluruhan di lingkungan Universitas Pendidikan Indonesia khususnya di Fakultas Ilmu Pendidikan bisa jadi kurang efektif jika tidak di barengi dengan peningkatan kualitas dosen. Kompetensi tenaga dosen dan 
tenaga administasi terdiri dari kemampuan dalam ilmu pengetahuan yang akan diajarkan, keterampilan dan attitude/personallity. Bagi tenaga dosen pengetahuan yang dimilikinya difokuskan pada pengetahuan mengenai ilmu-ilmu yang akan diajarkan. Pengetahuan akan ilmu-ilmu yang akan diajarkan oleh tenaga dosen secara umum di lingkungan Fakultas Ilmu Pendidikan Universitas Pendidikan Indonesia sudah baik. Hal ini terlihat dari respon yang tinggi terhadap perkembangan ilmu pengetahuan.

\section{Mutu Layanan di Lingkungan}

Fakultas Ilmu Pendidikan Universitas Pendidikan Indonesia.

Berdasarkan temuan di lapangan, bahwa lembaga pihak Fakultas Ilmu Pendidikan umumnya Universitas Pendidikan Indonesia orientasi terhadap mutu layanan telah dilakukan. Berbagai kebijakan dan program-program dilaksanakan untuk meningkatkan kualitas pelayanan, seperti dalam peningkatan kualitas sarana dan prasarana serta, penyederhanaan birokrasi dan aplikasi teknologi. Ketiga hal tersebut memberikan dampak yang sangat baik terhadap kepuasan pelanggan terutama mahasiswa. Peningkatan kualitas sarana dan prasarana seperti gedung dan ruang kelas telah dimulai di tingkat Universitas Pendidikan Indonesia khususnya di Fakultas Ilmu pendidikan. Perubahan membutuhkan pengorbanan, begitu juga dalam hal peningkatan kualitas sarana dan prasarana di lingkungan Fakultas Ilmu Pendidikan Universitas Pendidikan Indonesia memberikan dampak pada peralihan ruangan dan gedung sementara. Dengan perpindahan geddung dan ruang kelas tersebut proses belajar mengajar harus dan pelaksanaan manajemen dilakukan dengan fasilitas seadanya.

Pelayanan dalam pembelajaran yang baik akan memberikan kepercayaan bagi mahasiswa untuk yakin terhadap kualitas pendidikan pada jurusan yang ada di lingkungan Fakultas Ilmu Pendidikan. Pelayanan dalam pembelajaran tergantung pada kesiapan dosen dalam memberikan materi perkuliahan. Dosen harus mempunyai disiplin yang tinggi dan mempunyai rasa tanggung jawab terhadap ilmu yang diberikan kepada mahasiswa.

Untuk meningkatkan aspek responsivenes dalam mutu layanan perlu dilakukan berbagai survei ataupun kajian yang dilakukan secara terus menerus terhadap pelanggan khususnya mahasiswa. Kegiatan tersebut ditujukan untuk merespon segala kebutuhan mahasiswa yang menyangkut pelayanan akademik ataupun non akademik. Hal ini belum dilakukan secara optimal di lingkungan Fakultas Ilmu Pendidikan.

Kualitas dari lembaga salah satunya diukur dari output atau lulusan. Pemberian jaminan terhadap pelanggan khususnya mahasiswa yang akan lulus dan menghadapi dunia lapangan pekerjaan harus menjadi perhatian bagi lembaga khususnya yang berada di lingkungan 
Fakultas Ilmu Pendidikan. Pihak lembaga perlu mengembangkan sebuah desain dalam penyaluran lulusan menuju dunia kerja. Hal ini belum sepenuhnya dioptimalkan oleh fihak lembaga ataupun jurusan-juruan yang berada di lingkungan Fakultas Ilmu Pendidikan. Hal ini mengakibatkan banyaknya lulusan yang masih mempertanyakan pemberian jaminan dari lembaga akan tanggung jawab lembaga dalam menyalurkan mereka kedunia lapangan pekerjaan. Pemberian jaminan terhadap pelanggan, artinya mereka kuliah di jurusan tertentu harus diberikan jaminan kualitas dan prosfek yang baik dari lembaga.

Dalam kenyataannya di lingkungan Fakultas Ilmu Pendidikan berdasarkan temuan dari hasil penelitian kesiapan tenaga dosen dan tenaga administrasi dalam pemakaian Bahasa Inggris belum memenuhi standar kriteria. Begitu juga mengenai fasilitas di lingkungan Fakultas Ilmu Pendidikan masih terhambat oleh adanya renovasi bangunan. Disamping itu juga kualitas dari penguasaan Bahasa Inggris mahasiswa yang berada di lingkungan Fakultas Ilmu Pendidikan cukup rendah, yang mengakibatkan kualitas lulusannya yang kurang mampu bersaing ditingkat internasional bahkan nasional dalam hal keterampilan Bahasa Inggris.

Berdasarkan hal tersebut perlu adanya suatu pelaksanaan program Internasionalisasi untuk Membangun daya saing nasional pada unit kerja fakultas ilmu pendidikan Universitas pendidikan indonesia. Secara umum tujuan dilaksanakannya program internasionalisasi adalah untuk meningkatkan daya saing jurusan-jurusan yang berada di lingkungan Fakultas Ilmu Pendidikan Universitas Pendidikan Indonesia secara nasional ataupun internasional .

Sedangkan tujuan secara khusus adalah: Menyongsong pelaksanaan leading and outstanding university; Meningkatkan orientasi dan kualitas lulusan; Meningkatkan keterampilan berbahasa Inggris bagi dosen, tenaga adaministrasi dan mahasiswa; meningkatkan kualitas sarana dan prasrana; meningkatkan penerapan teknologi informasi dalam berbagai aspek pendukung kegaitan manajemen dan pembelajaran dan memberikan bimbingan yang yang terus menerus pada jurusanjurusan yang ada di lingkungan Fakultas Ilmu Pendidikan untuk mempersiapkan dan membuka kelas internasional.

Sasaran dari rancangan program internasionalisasi adalah seluruh tenaga dosen, staf administrasi dan pimpinan jurusan yang berada di lingkungan Fakultas Ilmu Pendidikan Universitas Pendidikan Indonesia. Model pelaksanaan program internasionaisasi diawali dengan melakukan analisis lingkungan internal, analisis lingkungan eksternal dan sumber daya. Pada analisis lingkungan internal dilakukan dengan menganalisis kekuatan dan kelemahan yang ada di lingkungan 
Fakultas Ilmu Pendidikan, sedangkan untuk analisis lingkungan eksternal dapat dilakukan dengan menganalisis peluang dan tantangan yang dihadapi.

Aspek sumber daya memiliki peranan yang sangat penting sekali dalam keberhasilan program ini. Yang dimaksud dengan sumber daya adalah: Man atau manusia. Pimpinan Fakultas, Pimpinan Jurusan, Pimpinan Lab, dosen, tenaga administrasi dan mahasiswa, Material. Segala fasiliats pendukung seperti sarana dan prasrana yang ada dan Modal. Sumber dana.

\section{E. KESIMPULAN}

Sistem kelembagaan di lingkungan Fakultas Ilmu Pendidikan Universitas Pendidikan Indonesia dilandasi oleh visi Universitas Pendidikan Indonesia sebagai Universitas Pelopor dan Unggul (a leading and outstanding university) dalam disiplin ilmu pendidikan dan pendidikan displin ilmu di Indonesia pada 2010, dan menjadi salah satu universitas pelopor dan unggul di asia pada 2025.

Penataan sistem kelembagaan diwujudkan dalam beberapa program seperti: 1) Restrukturisasi organisasi dan penataan sistem manajemen sesuai dengan AD/ART;2) Penyusunan prosedur dan tata kerja baru sesuai dengan pembaruan yang telah ditetapkan; 3) Pennyiapan perngkat aturan untuk memfungsikan keseluruhan komponen manajemen kelembagaan sesuai dengan sistem yang baru; 4) Pengembangan sistem manajemen keuangan; 5) Pengembangan sistem akuntabilitas kinerja dan penjaminan mutu; Pengembangan sistem manjemen perguruan tinggi modern berstandar internasional; 6) Peningkatan kinerja manajemen kampus daerah; 7) Peningkatan kinerja manajemen sekolah laboratorium-percontohan; 8) Penataan dan pemberdayaan unit bisnis pendukung dan unit-unit pendukung lainnya, sesuai dengan ketentuan AD/ART; dan 9) Pengembangan sistem manajemen penghematan energi.

Sistem kepegawaian di lingkungan Fakultas Ilmu Pendidikan Universitas Pendidikan Indoenesia dilihat dari pela ks a na n rekruitmen, pengembangan/pembinaan, penggajian dan pemberhentian/ pemensiunan. Permasalahan yang terjadi adalah 1) Belum mengoptimalkan sistem pengkaderan tenaga dosen dari mahasiswa yang ada di lingkungan FIP untuk direkrut menjadi tenaga dosen. 2) Sistem birokrasi yang masih kental dalam hal pembinaan pegawai, seperti dalam kenaikan tingkat/jabatan. 3) Sistem penggajian yang belum optimal bagi tenaga dosen.

Dalam hal kompetensi tenaga dosen ataupun tenaga administrasi di lingkungan Fakultas Ilmu Pendidikan Universitas Pendidikan Indonesia sudah baik, hanya saja terdapat kelemahan diantaranya adalah 1) Penguasaan terhadap teknologi. Artinya masih ada tenaga dosen ataupun 
tenaga administrasi yang belum terampil dalam hal penggunaan teknologi. 2) Keterampilan bahasa Inggris. Mayoritas tenaga dosen dan tenaga administrasi di lingkungan Fakultas Ilmu Pendidikan Universitas Pendidikan Indonesia belum baik.

Gambaran mutu layanan di Fakultas Ilmu Pendidikan Universitas Pendidikan Indonesia sudah baik, hanya saja memiliki berbagai permasalahan diantaranya adalah: 1) aspek responsip terhadap kebutuhan mahasiswa belum optimal dilakukan oleh lembaga 2) lembaga belum mampu mengoptimal kan pemberian jaminan bagi mahasiswa terutama dalam hal penyaluran kerja.

R a n c a n g a p r o g r a m internasionalisai pada unit kerja di lingkungan Fakultas Ilmu Pendidikan Universitas Pendidikan Indonesia di tujukan untuk meningkatkan daya saing lembaga secara nasional. Rancangan program ini diuraikan dalam tujuan, sasaran dan strategi operasional.

\section{DAFTAR PUSTAKA}

Ana Mariana. (2002). Pengembagan Pendidikan Tinggi. Disertasi UNY.

Boulter, N. (2003). The Leadership at Higher Education, Mc Graw Hills USA.

Hornby. (1962). Qualitative Research for Education: An Introduction to Theory and Methods. London;
Allyn and Bacon.Inc.

Johnson. (1974). The Analicis of Educational Productivity Volume II: Issues in Microanalicis. Ballinger Publishing Company: Massachusetts.

Medriati, R. (2013). Pengembangan Model Siklus Belajar (Learning Cycle) Untuk Meningkatkan Kemampuan Penguasaan Aplikasi Konsep: Studi Pengembangan Model Pembelajaran Untuk Bidang Sains Di Sekolah Dasar (Doctoral dissertation, Universitas Pendidikan Indonesia).

PERC (2001), Political and Economic Risk Consultancy (PERC) The Jakarta Post (Vol.19, No.127: 2001),

Peraturan Pemerintah. (1996). Peraturan Pemerintah Nomor 41996 tentang Pemberhentian PNS.

Peraturan Pemerintah. (2003). Peraturan nomor 9 tahun 2003 tentang Penetapan PNS.

Peraturan Pemerintah. (2004). Peraturan Pemerintah Nomor 59 tahun 2007 tentang Tunjangan Dosen PNS.

Poerwadarminta. (1994). Kamus Besar Bahasa Indonesia. Pustaka Karya Indonesia.

Posuma, C. O. (2013). Kompetensi, kompensasi, dan kepemimpinan pengaruhnya terhadap kinerja karyawan pada Rumah Sakit Ratumbuysang Manado. Jurnal EMBA: Jurnal Riset Ekonomi, 
PEDAGOGIA : Jurnal IImu Pendidikan

Manajemen, Bisnis dan Akuntansi, 1(4).

Rais, N. A. (2014). Keefektifan Kegiatan

Pengayaan Pembelajaran

Multimedia Melalui Jargoone. Tv

Sebagai Upaya Peningkatan

Kompetensi Produktif Siswa Di

Smk N 11 Semarang (Doctoral dissertation, Universitas Negeri

Semarang).

Rencana Strategis UPI. (2010). Pedoman

Akademik Universitas Pendidikan

Indonesia.

Rinala, I. N., Yudana, I. M., \& Natajaya, I.

N. (2013). Pengaruh Kualitas

Pelayanan Akademik Terhadap

Kepuasan dan Loyalitas

Mahasiswa Pada Sekolah Tinggi

Pariwisata Nusa Dua Bali. Jurnal

Administrasi Pendidikan

Indonesia, 4(1).

Santiasih, N. W. (2013). Pengaruh

Kompetensi Pegawai terhadap Kinerja Pegawai di Kantor Camat

Pupuan Kabupaten Tabanan

Tahun 2012. Jurnal Pendidikan

Ekonomi Undiksha, 3(1).

Zeithani \& Berry. (1985). Management

Information system, A Study of Computer Based Information System. 6 Edition. Jakarta: PT Prenhallindo. 